\title{
Relevance of social capital in women's business performance in Bangladesh
}

\author{
L. Mozumdar, K. S. Farid* and P. K. Sarma ${ }^{1}$ \\ Department of Rural Sociology and ${ }^{1}$ Bangladesh Agricultural University Research System (BAURES) \\ Bangladesh Agricultural University, Mymensingh-2202, Bangladesh, *E-mail: ksfarid@bau.edu.bd
}

\begin{abstract}
Social capital has been projected as a key resource in entrepreneurial success. While the association between successful business activity by rural women and their ability in building social capital is often seen as a pathway of poverty reduction, a thorough understanding of the relevance of social capital in women's business performance could have crucial insights into ways for alleviating rural poverty in developing countries. Nonetheless, the relevance of social capital in women's business performance has hardly studied in the specific context of Bangladesh. The present review is undertaken to fill this information gap. Social capital has positive impact on gaining legitimacy, building mutual trust and co-operation in women's business. Besides, women enterprises with enhanced social capital are found to possess better access to other forms of capital. The review shows the importance of external actors such as microfinance institutions in developing social capital of women enterprises in Bangladesh. Alongside microfinance, regulative factors such as different rules and regulations of the government can positively facilitate women entrepreneurship development in rural Bangladesh.
\end{abstract}

Keywords: Social network, Impact, Entrepreneurship, Cooperation

\section{Introduction}

Women in developing countries are more vulnerable to socio-economic shocks and experience high degree of poverty on a regular basis than men (Cleaver, 1998). Building social capital that stimulates their business activity is a sustainable manner to break them out of poverty traps (Bruton et al., 2013). Because, businesses run by women not only promote their empowerment, create a resilient and more independent societal position, but also support family incomes (Moller, 2012). Although women in developing countries take their own specific societal based position within their societies, particularly in case of women living in poor circumstances (for example, women of rural Bangladesh), their actions are largely dependent on their spouses as well as social setting they live in (Kuada, 2009). Bangladesh-a country mostly confined to traditional social setting where women have a highly marginalized social position could have significant limitations to venture into businesses (Cleaver, 1998). For example, only $0.9 \%$ of the Bangladeshi women venture into business activities unlike other countries of Asia viz. China (8.7\%) and India (5.2\%) (Mascarenhas-Keyes, 2006). On the other hand, evidences suggest that business activities of women improve their personal income, dignity (Awusabo-Asare and Tanle, 2008), and livelihoods (Moller, 2012; Ramswamy and Kumar, 2013). Successful women businesses also accomplish growth by the use of social interactions, social relations (for instances, relationships with friends and relatives) and developing interpersonal relationships i.e. by building social capital (Bennet and Richardson, 2005; Roomi, 2006). While the strong association between successful business activity by rural women and their ability in building social capital is often seen as a pathway out of poverty (Maas et al.,2014), a thorough understanding of the relevance of social capital in women's business performance could have crucial insights into ways for alleviating rural poverty in developing countries. Nonetheless, the relevance of social capital in women's business performance has been hardly studied in the specific context of Bangladesh. The present review is undertaken to fill this information gap. The objective of this review is to explore the relevance of social capital in women's business performance in Bangladesh. More specifically, we explore (1) how does social capital impact women's business performance in Bangladesh? (2) What drives social capital in women's business performance in Bangladesh?

\section{Materials and Methods}

A search strategy was developed to retrieve all documents (journal articles, reports, popular articles, policy briefs) on studies that considered the relationship between the social capital and women's business performance in Bangladesh. Firstly, a search was initiated in the online electronic databases (Scopus, 
Web of science, Elsevier Science Direct and Google Scholar) using combinations of keywords related to entrepreneurship (e.g. women enterprises, women business, women entrepreneur), networks (e.g. social capital), setting (e.g. developing countries, Bangladesh) and performance outcomes (e.g. business growth, business performance). Studies were included regardless of study design, setting, measurement techniques, type of outcomes and date of publication. Language restrictions were applied. Only those literature published in English were included. An example for the search strategy followed in Scopus for this study is reported in Table1. Grey literature and information from websites and news reports were also included. A total of 446 (440 from Scopus +6 Grey literature) documents were retrieved, out of which 85 studies were selected after scrutinizing the title and abstract. Finally, 55 studies were used for this review based on two inclusion criteria: (1) findings' focus on the research questions; (2) soundness and relevancy of research methods.

Table 1. Search strategy in Scopus

\begin{tabular}{lc}
\hline Keyword combination & No. of results \\
\hline women enterprises AND women entrepreneur AND social capital & 62 \\
women business AND social capital & 186 \\
women self-help groups AND social capital & 23 \\
women AND small-medium enterprises & 143 \\
women enterprises AND Bangladesh AND social capital & 2 \\
women business AND microfinance AND social capital & 6 \\
women enterprise AND business performance AND business growth & 18 \\
AND social capital & \\
\hline Total & $\mathbf{4 4 0}$ \\
\hline
\end{tabular}

\section{Results and Discussion}

\section{Meaning, types and sources of social capital}

Before answering the research questions, it is important to define the concept of "Social capital" as well as what constitutes women's business in this study. Although, the definition and concept of social capital is highly debated, most literatures agree that social capital is the goodwill that is engendered by the fabric of social relations such as trust, norms, and networks that can be mobilized to improve the efficiency of society by facilitating coordinated actions (Putnam,1993; Adler and Kwoon, 2002; Westlund and Bolton, 2003). While gender is considered limitedly in the literature on social capital (Norton, 2001), its importance in uplifting rural women in case of developing countries is significant, as there is evidence that women are excluded from high ranking, powerful, male-oriented networks (Silvey and Elmhirst, 2003). On the other hand, notwithstanding women's role as main actors in the construction of intra-household social capital (Putnam, 2000), their networks outside their home surroundings are rather limited and remains critical for business success. For accomplishing business, Long (1999) contends that the most critical needs of women entrepreneurs are not related to technical areas but to non-technical areas. According to him, while the technical needs are the same irrespective of gender, the non-technical needs such as development of relevant forms of social capital and mentors have far-reaching effects on women entrepreneurs than on men. Because, social capital in the form of networks helps women gain access to business advice, facilitates the formation of business partnerships and gives them access to alternative sources of financing (Kelley et al., 2010).

In general, three types of social capital have been distinguished in the literature on women's business performance. These are as follows:

- Bonding social capital: It can be considered a horizontal relationship by which members of the same group or community strengthen their ties (Putnam, 2002).

- Bridging social capital: It refers to members of a particular group establishing "bridges" with other groups or organizations, for example business associates or people from different groups (Narayan, 2002).

- Linking social capital: It is characterized by connections between those with different levels of power or social status (Aldridge et al., 2002). 
These types of social capital increase business performance (Bruderl and Preisendorfer, 1998) by improved access to financial capital (Dyer and Mortensen, 2005; Casson and Giusta, 2007) and support during hostile environment, like cyclones (Hawkins and Maurer, 2010) or act as emotional support (Wood et al., 2013). While these three types of social capitals are important in deciding the success of any business, some scholars have identified its sources viz. networks, trust and norms as equally important (Kim and Aldrich, 2005). In view of the relevance of both the types and sources of social capital, this review has made an effort to present the focus, sources and types of its impact on women's business in Bangladesh (Table 2).

Table 2. Selected literatures discussing impact of social capital on women's business performance in Bangladesh

\begin{tabular}{|c|c|c|c|c|c|}
\hline $\begin{array}{l}\text { Type of } \\
\text { business }\end{array}$ & Focus and impacts & $\begin{array}{l}\text { Type of social } \\
\text { capital discussed }\end{array}$ & $\begin{array}{l}\text { Sources of social } \\
\text { capital discussed }\end{array}$ & Methods & Sources \\
\hline Co-operative & Norms, values, trust & Bridging ties & Norms and trust & $\begin{array}{l}\text { Life history analysis of } 10 \\
\text { samples for } 2 \text { decades }\end{array}$ & Forsslund (1995) \\
\hline $\begin{array}{l}\text { Self Help } \\
\text { Groups } \\
\text { (SHGs ) }\end{array}$ & Norms, values, trust & $\begin{array}{l}\text { Bridging, bonding } \\
\text { and network ties }\end{array}$ & $\begin{array}{l}\text { Norms, trust and } \\
\text { networks }\end{array}$ & $\begin{array}{l}\text { In-depth interviews and } \\
\text { case studies }\end{array}$ & $\begin{array}{l}\text { Dowla (2006); } \\
\text { Sultana (2010) }\end{array}$ \\
\hline $\begin{array}{l}\text { Small and } \\
\text { Medium } \\
\text { Enterprises } \\
\text { (SMEs ) }\end{array}$ & $\begin{array}{l}\text { Adopting a social capital } \\
\text { perspective on network } \\
\text { formation and } \\
\text { development }\end{array}$ & $\begin{array}{l}\text { Bridging and } \\
\text { bonding network } \\
\text { ties }\end{array}$ & Networks & $\begin{array}{l}\text { longitudinal data on } 26 \\
\text { samples gathered over } \\
\text { two years }\end{array}$ & Maas et al. (2014) \\
\hline
\end{tabular}

\section{Women's business in Bangladesh}

It is important to define what constitute women's business in Bangladesh. Government of Bangladesh has given a broader definition of the term women business. It defines women business as "an enterprise owned and controlled by women having a minimum financial interest of $51 \%$ of the capital and giving at least $51 \%$ of the employment generated in the enterprise to women" (Sultana, 2012). Unlike developed countries, where single owned or family businesses are frequent, women's business in Bangladesh mainly take the form of (1) co-operatives, (2) self-help groups (SHGs), and (3) small and medium enterprises (SMEs) (Chowdhury, 1988). According to Nawaz (2009), this is largely owing to their societal position as well as prevailing cultural and religious systems that prevent them from taking apex management positions in single owned or family businesses. Generally, social customs and strong religious barriers to which rural Bangladeshi women are bound often prevent them from business operations (Sultana, 2010). Women observing "purdah" (seclusion-the practice in certain Muslim societies of screening women from men or strangers, especially by means of a veil) often find it difficult to visit banks, purchase their inputs or raw materials or market their product in public settings where they would have to deal with men (Rahman et al., 2000). Besides traditional customs and religious barriers, the economic capacity and assets of women in Bangladesh are capped at levels substantially lower than that for starting a business (Karim, 2001). As such, women's businesses are built around the support of external actors (For e.g., Microfinance institutions). Studies on women empowerment in Bangladesh also relate the concept of social capital in terms of microfinance (Larance, 1998; Dowla, 2006). Microfinance institutions facilitate women's business activity by forming small self-help groups, women's co-operatives and small medium enterprises (Sultana, 2012), and therefore this review confines the type of women's business in Bangladesh to the above three types. Table 3 shows the major sector of investments in business by rural women in Bangladesh. Being an agrarian country, with agriculture contributing $15.35 \%$ of the national GDP (MoF, 2016), majority of the women entrepreneurs in Bangladesh (27\%) are engaged in agriculture and livestock related business. Trading of agricultural products comes next (21\%), followed by grocery shops (14\%) and renting of vehicles (12\%). Almost $16 \%$ of women's businesses in the country focus on managing stores (8\%) or small business and services (8\%). 
Table 3. Major sector of investments in business by rural women in Bangladesh

\begin{tabular}{lc}
\hline Sectors & Percentage \\
\hline Agriculture and livestock production & 27 \\
Trading agricultural products & 21 \\
Grocery shops & 14 \\
Renting vehicles (For e.g. bicycles and rickshaws) & 12 \\
Handicrafts (pottery, jute and bamboo products) & 10 \\
Variety stores (ladies garments, confectionary and cosmetics & 8 \\
Small business and services (tailoring, tea stall and restaurants) & 8 \\
\hline
\end{tabular}

Source: Jahiruddin et al. (2011)

\section{Impact of social capital on women's business performance}

There is a positive and significant relationship between social capital and entrepreneurship. Social capital is a strong factor that plays an important role in developing strategies, which can create an innovative culture and provoke innovation by inspiring trust and trusting in values and leadership principles (Fabova and Janakova, 2015). Social capital is an intangible asset (Adler and Kwon, 2002), which plays significant role in entrepreneurial activities, the existence or absence of which can influence business performance. Social capital is, therefore, a key component of entrepreneurship without which a business cannot be established and might face several problems. Recent studies reveal that the relationship between woman entrepreneurs and social capital is especially noteworthy (Chung et al., 2012). Social capital and social networking is important for female business owners as it can increase the success rate of their business (Sharafizad, 2011). The impact of social capital on women's business performance in Bangladesh is discussed here in terms of legitimacy of women's business, building inter and intra business trust, increasing innovative capability of women entrepreneurs, building co-operation, improving access to other forms of capital.

\section{Social capital and legitimacy of women's business}

Liao and Welsch (2005) argue that social capital not only enhances individual entrepreneurial ability to make assertive business decisions but also helps firms to acquire organizational legitimacy and reputation. The acquired reputation facilitates their access to external resources and may replace their lack of experience and record of accomplishment (Stuart et al., 1999). Dowla (2006) through the example of Grameen Bank shows that focused attempts to create (social capital) trust, norms and networks have fundamentally changed the lives of the women SHG members in rural Bangladesh engaged in small businesses. According to him, the trust in poor people's ability to repay loans constituted a collective capital that enabled them to access others forms of credit from commercial banks as well. Besides, the presence of trust among SHG members has narrowed the need to use costly safeguards and monitoring that would otherwise be necessary to affect most transactions in a business environment (Arrow, 1974). The repayment rate was high among the women SHGs involved in small business compared to the low repayment rate of commercial sector. These high repayment rates were created because of social capital and capacity building efforts of the external actors such as Grameen Bank and BRAC. Once Grameen Bank established the trust in poor people's ability to repay, others could benefit from this generalized trust and legitimacy-a public good (Dowla, 2006). Nevertheless, even in cases like the Grameen Bank that has been praised for its capability in raising the social capital and general trust in women businesses by forming SHGs, recent research suggests that richer women benefit from microfinance much more than poorer ones due to their societal position and reputation (Lamia, 2011).

\section{Social capital and building inter and intra business trust}

The case analysis of SHGs by Sultana (2010) shows that women's participation in home-based traditional business can significantly build social capital, create awareness and enhance their capability to uplift their position in the society. Self-help groups have facilitated the formation of social capital among rural women, where they learn to work together for a common purpose in a group or organization. Larence (2001) from his village level investigation of women businesses managed by SHGs, note the example of 
conforming to "meeting norms" that enabled women to establish individual identities. The group's interactions at regular center meetings facilitate collective identity and mutual trust among the members. The trust becomes stronger with the network expansion and frequent interactions when increasing numbers of redundant ties are formed. These stronger and redundant ties allow for an easier flow of information and access to labour, knowledge and other pooled resources. This is however at odds with the many corporate studies which indicate that weak ties and an abundance of structural holes increase the entrepreneurial value of social capital (Burt, 2001). Most of the entrepreneurial activities of women in Bangladesh were based on resources acquired through the strong, horizontal bridging ties: labour, money, knowledge, safety, ideas, food and other materials (Maas et al., 2014). During the initial phases, SHGs were found to operate under low-trust environment with weak ties among members (intra-business trust) and outside the group (inter-business trust). Only after these ties become stronger, can people rely on the other person's competences and benevolence. When the network grows bigger and the SHGs create vertical linking ties, both intra and inter business trust is strongly established (Maas et al., 2014). This implies that formation of SHGs and networking can be an important strategy to stimulate business performance among Bangladeshi women living in resource-constrained environments (Wood and McKinley, 2010).

\section{Increasing innovative capability of women entrepreneurs}

Innovation is an essential trait needed for long-term business success (Malhotra et al., 2009). Although human capital like the level knowledge or education and previous business experiences influence innovative capacity, the firm's social capital forms one of the crucial indicators of innovation and business performance. Strong social capital with affluent heterogeneous networks are not only deemed essential for successful venturing and long term growth orientation in women owned business (Harding, 2007) but also considered indispensable for firm's innovative capacity (Sappleton, 2009). However, individual business expertise appears to be linked with novelty oriented innovations, whereas women's SHG experience seems to be associated with differentiation oriented innovations (Dowla, 2006). While financial capital, specifically the commercial or private lending, initially can assist a lot to generate individual firm income through self-developed micro-business or self-employment, private lending or bank loans are often seen as a high-risk debt for the SHGs comprising poor women in developing countries (Karim, 2001). The indebtedness may decrease both the differentiation-related and novelty-oriented innovations. On the other hand, micro-finance offered by Grameen Bank and BRAC helps to build social capital as well as social networks by strengthening weak ties within women networks. Developing weak ties into strong bonding and bridging is therefore a great basis of support in business development since linkage with micro credit lending groups increases the prospect of both the differentiation- and novelty-oriented innovation (Maas et al., 2014). These findings by Maas et al. (2014) disagree with the findings of Bradley et al. (2012) while they link network diversity positively to business performance, their findings associate strong ties with loss of innovation capabilities.

\section{Building co-operation}

The joint group participation, especially in income generating projects, provides opportunity for women to learn new skills, whilst developing cooperation, trust, respect, and deriving an increased income (Janssens, 2010; Morduch, 2000; Swain and Wallentin, 2009). A recent study by Karim et al. (2001) on MIDI (Micro Enterprise Development Initiative) of MIDAS (Micro Industries Development Assistance and Services) in Bangladesh is a fine example of how improving social capital by networking and co-operation increased opportunities for reducing operating costs and increasing marketing. MIDAS MIDI credit borrowers are a group of women SMEs. They were facing many problems in marketing their products. They could not rent a house or a shop since the micro-credits were capped at low levels, and they were offering relatively few products to break the even. Therefore, twenty female MIDAS borrowers rented a house together and jointly started a mini-market selling only their own products. Each contributes 52 US\$ per month to meet the costs of rent, manager, and sales staff. Each product carries a code number, and, at the end of the week, the members collect their respective sale proceeds. MIDAS provides a good example of successful group marketing by women entrepreneurs by building co-operation. 


\section{Improving access to other forms of capital}

Since social capital is a public good (non-excludable)- the market may provide such good. Building social capital can therefore correct another type of market failure under provision of a public good, in addition to correcting the failure of the credit market. For instance, building social capital by Grameen Bank facilitates strong bonding, bridging, network ties within and outside women SHGs. The high rate of repayment of micro-finance loans (98\%) by women SHGs increases their trust and reputation among other lenders (commercial banks). The re-financing of micro-credits by commercial banks enables women enterprises to avail and access financial capital for expanding the business. Many of the micro-finance schemes in Bangladesh are linked with skill development such as handicrafts, embroidery and pottery. At the start of the business operation and planning, strong bonding and affective ties (relationship or ties with husbands and relatives) discourage development of women's business, while the weak/bridging ties stimulate them and provide them with the human capital to develop both their networks and entrepreneurial activities (Maas et al., 2014). Regardless of the differences in their approaches, most of the micro-finance programmes in the country are widely acknowledged to have been successful over the years in contributing to building bridging ties rather than bonding ties, and empowering women by strengthening their level of financial and human capital.

\section{What drives social capital in women's business performance?}

A variety of factors can drive social capital in women's business performance in Bangladesh. These include regulative, normative and cognitive factors (Nawaz, 2009; Sultana et al., 2010). Regulative factors such as different rules and regulations of the government can positively facilitate women entrepreneurship development in rural Bangladesh. While the articles 26, 27 and 28 of the Constitution of the People's Republic of Bangladesh have distinctly mentioned the issue of emancipation and development of the women folk of the country, there are no specific rules or laws that support women's economic participation. The exercise of normative factors like patriarchal norms, values and social customs as well as cognitive factors such as lack of education and business skills of the women may have negative impacts on their business development. Less opportunity to access to the market and lack of infrastructural facilities are found to hinder the women's micro entrepreneurship in rural Bangladesh (Sultana et al., 2010). On the other hand, the desire for financial independence and decision-making, market and informational network, availability of a start-up capital, business knowledge and skills, and responsibility towards children are the main factors that impact women's decision to become selfentrepreneurs (Hossain et al., 2009). Women's participation in associations, advocacy (social capital), and decision-making (self-fulfillment) and knowledge are the main factors that affect women's decision to develop their business (Hossain et al., 2009).

By adopting a social capital perspective on network formation and development, Maas et al. (2014) identify four essential strategies in building entrepreneurial networks by women groups. These are (1) modifying and building on existing bonding networks, (2) transferring linking ties, (3) teaching how to build bridging networks, and (4) the creation of a network of entrepreneurial peers. They found that a third party such as Grameen Bank or BRAC could successfully stimulate network development for the poorest in Bangladesh. Therefore, this study suggests that governmental and non-governmental organizations need to take more initiatives to increase women's participation in the credit-based small businesses. Women should have easy access to loans, suitable business and the market. They should also be provided with basic education and training to create awareness, increase knowledge on business and the market, build capabilities and to promote business environment. Finally, as the entrepreneurial aspirations of women in Bangladesh are more a circumstantial decision impacted by the complex interplay of factors cited above, rather than something that has been nurtured from childhood and bloomed in adulthood, policies that favor creation of social capital in women and removing institutional barriers could stimulate the hidden human capital of entrepreneurship in them. 


\section{Conclusion}

This review builds on existing literature to highlight relevance of social capital on women's business performance in Bangladesh. As there are only few studies that directly address the relevance of social capital in women's business performance in Bangladesh context, inferences were largely made from studies related to microfinance and women empowerment. The present study found that the poor women in rural Bangladesh borrow some small loans from the micro-credit institutions to start small businesses. Social capital had positive impact on women's business in Bangladesh by (1) bringing legitimacy to the firm (2) building intra and inter-business trust, (3) developing innovative capacity, (4) co-operation, and (5) improved access to other forms of capital. The review also shows how external actors such as Grameen Bank and BRAC were able to create women's social capital that has been a boon to stimulate women's business performance. Microfinance institutions created social capital by forming horizontal and vertical networks, establishing new norms and fostering a new level of social trust to solve the collective action problems of poor women's access to financial and human capital. Women's participation in associations, advocacy (social capital), and decision-making (self-fulfillment) and knowledge are the main factors that affect women's decision to develop their business. Alongside microfinance, regulative factors such as different rules and regulations of the government can positively facilitate women entrepreneurship development in rural Bangladesh. The fact that a microfinance Institution can create social capital in improving business performance of women enterprises in Bangladesh has strong policy implications.

\section{References}

Adler, P. and Kwon, S.W. 2002. Social capital: Prospects for a new concept. Academy of Management Review, 27(1): 17-40.

Aldridge, S., Halpern, D. and Fitzpatrick, S. 2002. Social capital: A discussion paper. London, UK: Performance and Innovation Unit.

Arrow, K. J. 1974. The limits to organizations. New York: Norton.

Awusabo-Asare, K. and Tanle, A. 2008. Eking a living: Women entrepreneurship and poverty reduction strategies: The case of palm kernel oil processing in the Central Region of Ghana. Norwegian Journal of Geography, 62(3): 149-160.

Bennet, D. and Richardson, P. 2005. Building relationships and social capital development. Paper presented at the 50th ICSB World Conference, Washington DC.

Bradley, S.W., McMullen, J.S. Artz, K. and Simiyu, E.M. 2012. Capital is not enough: Innovation in developing economies. The Journal of Management Studies, 49(4): 684-717.

Bruderl, J. and Preisendorfer, P. 1998. Network support and the success of newly founded business. Small Business Economics, 10(3): 213-225.

Bruton, G.D., Ketchen Jr, D.J. and Ireland, R.D. 2013. Entrepreneurship as a solution to poverty. Journal of Business Venturing, 28(6): 683-689.

Burt, R.S. 2001. Structural holes versus network closure as social capital. In R.S.B. Nan Lin and K.S. Cook (Eds.), Social capital: theory and research. New York: Aldine de Gruyter.

Casson, M. and Giusta, M.D. 2007. Entrepreneurship and social capital - Analysing the impact of social networks on entrepreneurial activity from a rational action perspective. International Small Business Journal, 25(3): 220-244.

Chowdhury, A. M. 1988. The Emergence of Growth of Entrepreneur in some developing countries. Dhaka .Univ. Stu. Part C, IX (1).

Chuang, L.M., Kiu, C.C., Huang, C.M. \& Tang, H.C. 2012. An Evaluation Model of Female Entrepreneurship in the Service IndustryHuman Capital, Social Capital and Opportunity Recognition Perspective. International Research Journal of Finance and Economics, 85: 56-67.

Cleaver, F. 1998. Choice, complexity, and change: Gendered livelihoods and the management of water. Agriculture and Human Values, 15(4): 293-299.

Dowla, A. 2006. In credit we trust: Building social capital by Grameen Bank in Bangladesh. The Journal of Socio-Economics, 35(1): $102-122$.

Dyer, W.G. and Mortensen, S.P. 2005. Entrepreneurship and family business in a hostile environment: The case of Lithuania. Family Business Review, 18(3): 247-258.

Fabova, L. and Janakova, H. 2015. Impact of the business environment on development of innovation in Slovak Republic, Procedia Economics and Finance, 34: 66-72.

Forsslund, A. 1995. From nobody to somebody: Women's struggle to achieve dignity and self-reliance in a Bangladeshi village. Department of Education, University of Umea.

Harding, R. 2007. State of women's enterprise in the UK. Prowess, Norwich, CT.

Hawkins, R. L. and Maurer, K. 2010. Bonding, bridging and linking: How social capital operated in New Orleans following Hurricane Katrina. British Journal of Social Work, 40(6): 1777-1793.

Hossain A., Naser, K., Zaman A. and Nuseibeh, R. 2009. Factors influencing women business development in the developing countries: Evidence from Bangladesh. International Journal of Organizational Analysis, 17(3): 202-224. 
Jahiruddin A.T.M., Short, P., Dressler, W. and Khan, M.A. 2011. Can microcredit worsen poverty? Cases of exacerbated poverty in Bangladesh. Development in Practice, 21: 1109-1121.

Janssens, W. 2010. Women's empowerment and the creation of social capital in Indian villages. World Development, 38(7): 974988.

Karim N. A. 2001. Jobs, gender and small enterprises in Bangladesh: Factors affecting women entrepreneurs in small and cottage industries in Bangladesh. International Labour Organization.

Kelley, D.; Brush, C.; Greene, P. and Litovsky, Y. 2010. Global entrepreneurship monitor: 2010. Women's Report, Babson.

Kim, P. and Aldrich, H. 2005. Social capital and entrepreneurship. Delft: Now Publishers.

Kuada, J. 2009. Gender, social networks, and entrepreneurship in Ghana. Journal of African Business, 10(1): 85-103.

Lamia, K. 2011. Microfinance and its discontents: Women in debt in Bangladesh. Minneapolis, MN: University of Minnesota Press.

Larence, L.Y. 2001. Fostering social capital through NGO design: Grameen Bank membership in Bangladesh. International Social Work, 44(1): 7-18.

Liao, J. and Welsch, H. 2005. Roles of social capital in venture creation: key dimensions and research implications. Journal of Small Business Management, 43(4): 345-362.

Long, D. 1999. Women entrepreneurs: What do they need? Business and Economic Review, 45(4): 25-34.

Maas, J., Seferiadis, A., Bunders J.G. and Zweekhorst, M.M. 2014. Bridging the disconnect: How network creation facilitates female Bangladeshi entrepreneurship. International Entrepreneurship and Management Journal, 10(3): 457-470.

Malhotra, A., Schulte, J., Patel P. and Petesch, P. 2009. Innovation for women's empowerment and gender equality. International Centre for Research on Women. Washington DC. https://www.icrw.org/files/publications/Innovation-for-WomensEmpowerment.pdf

Mascarenhas-Keyes, S. 2006. Ethnic minority small and medium enterprise in England: Diversity and challenges. Paper presented to the 51st International Council of Small Business (ICSB) Conference, Melbourne, 18-21 June.

MoF (Ministry of Finance) 2016. Economic Adviser's Wing, Finance Division, Ministry of Finance, Government of the People's Republic of Bangladesh, Dhaka.

Moller, C. 2012. Gendered entrepreneurship in rural Latvia: Exploring femininities, work, and livelihood within rural tourism. Journal of Baltic Studies, 43(1): 75-94.

Morduch, J. 2000. The microfinance Schism. World Development, 24(4): 617-629.

Narayan, D. 2002. Bonds and bridges: Social capital and poverty. In: Isham, J., T. Kelly, and S. Ramaswamy (eds.) Social capital and economic development: Well-being in developing countries. Cheltenham, UK: Edward Elgar, 58-81.

Nawaz, F. 2009. Critical factors of women entrepreneurship development in rural Bangladesh. Bangladesh Development Research Working Paper Series, 5. Available at:http://www.bangladeshstudies.org/files/WPS_no5.pdf.

Norton, A. 2001. The market for social capital. Policy, 17(1): 40-44.

Putnam, R. D. 1993. Making democracy work: Civic traditions in modern Italy. Princeton, NJ: Princeton University Press.

Putnam, R. D. 2000. Bowling alone. The collapse and revival of American community, New York: Simon and Schuster.

Putnam, R. D. (ed.) 2002. The dynamics of social capital. Oxford: Oxford university press.

Rahman, M.M., Hossain, M.I. and Miah, A.S. 2000. Problems of women entrepreneurship development: A study of Grameen Bank finance on some selected areas. Islamic University Studies, 3: 124-128.

Ramswamy, R. and Kumar, N. 2013. Women weavers in Mizoram: Sustaining livelihood through cluster development. Indian Journal of Gender Studies, 20(3): 435-452.

Roomi, M.A. 2006. Women's entrepreneurship: A Systematic Review of Contemporary Perspectives. Paper presented at 51st ICSB Conference. Melbourne, Australia.

Sappleton, N. 2009. Women non-traditional entrepreneurs and social capital. International Journal of Gender and Entrepreneurship, 1(3): 198-218.

Sharafizad, J. 2011. Determinants of Business Networking Behaviour of Women in Small Business. Small Enterprise Research, 18:158-160

Silvey, R. and Elmhirst, R. 2003. Engendering social capital: Women workers and rural-urban networks in Indonesia's crisis. World development, 31(5): 865-879.

Stuart, T., Hoang, H. and Hybels, R. 1999. Inter-organizational endorsements and the performance of entrepreneurial ventures. Administrative Science Quarterly, 44(2): 315-349.

Sultana B., Zaaba, Z.B. and Umemoto, K. 2010. Women's empowerment through the development of micro entrepreneurship in rural Bangladesh. Social Science, 5:1-9.

Sultana, A. 2012. Promoting women's entrepreneurship through SME: Growth and development in the context of Bangladesh. IOSR Journal of Business and Management, 4(1): 18-29.

Swain, R. and Wallentin, F. 2009. Does microfinance empower women? Evidence from self-help groups in India. International Review of Applied Economics, 23(5): 541-556.

Westlund, H. and Bolton, R. 2003. Local social capital and entrepreneurship. Small Business Economics, 21(2): 77-113.

Wood, L.J., Boruff, B.J. and Smith, H.M. 2013. When disaster strikes how communities cope and adapt: A social capital perspective. Social Capital: Theory, Measurement and Outcomes: 141-169.

Wood, M.S. and McKinley, W. 2010. The production of entrepreneurial opportunity: A constructivist perspective. Strategic Entrepreneurship Journal, 4(1): 66-84. 